\title{
Schwann Cell Type V Collagen Inhibits Axonal Outgrowth and Promotes Schwann Cell Migration via Distinct Adhesive Activities of the Collagen and Noncollagen Domains
}

\author{
Michael A. Chernousov, Richard C. Stahl, and David J. Carey \\ Sigfried and Janet Weis Center for Research, Geisinger Clinic, Danville, Pennsylvania 17822-2613
}

Previously, we reported the cloning of $\alpha 4$ type $\mathrm{V}$ collagen, a novel member of the collagen type $V$ gene family that is expressed by Schwann cells in developing peripheral nerves (Chernousov et al., 2000). The present study was performed to investigate the effects of this collagen on the adhesion and migration of premyelinating Schwann cells and neurite outgrowth from embryonic dorsal root ganglion neurons. Purified $\alpha 4(\mathrm{~V})$-containing collagen isolated from Schwann cell conditioned medium (collagen type $\mathrm{V}_{\mathrm{SC}}$ ) promoted migration of Schwann cells but inhibited outgrowth of axons from rat embryo dorsal root ganglia. Collagen type $\mathrm{V}_{\mathrm{SC}}$ blocked axonal outgrowth in the presence of otherwise active substrates such as collagen type IV, indicative of active inhibition. The noncollagen N-terminal domain of $\alpha 4(\mathrm{~V})$ promoted Schwann cell adhesion, spreading, and migration. These processes were inhib-

During development cellular interactions with the extracellular matrix (ECM) regulate many aspects of cell function, including migration, cytoskeletal organization, proliferation, and differentiation. Interactions of cells with ECM molecules are mediated by cell surface receptors that display a range of binding specificities. The best-studied ECM receptors are the integrins (Hynes, 1992; Clark and Brugge, 1995). These transmembrane heterodimers bind ECM proteins and cytoplasmic structural and signaling proteins, thereby providing a mechanism for regulating cell function via ECM contact. Other proteins have also been shown to function as ECM receptors. The syndecan transmembrane proteoglycans, for example, bind ECM proteins via their attached heparan sulfate chains (Saunders and Bernfield, 1988; Elenius et al., 1990; Sanderson et al., 1992; Chernousov et al., 1996). Syndecans are also linked to cytosolic structural proteins (Rapraeger et al., 1986; Carey et al., 1996) and signaling proteins (Oh et al., 1997; Granes et al., 1999), providing an additional pathway for transduction of ECM-dependent signaling.

Our laboratory has been investigating the function of ECM proteins in the developing peripheral nervous system. We identified a heparin-binding protein that is expressed by Schwann cells in embryonic and early postnatal nerves (Chernousov et al., 1996; Chernousov et al., 1999). Molecular cloning identified this

\footnotetext{
Received Feb. 9, 2001; revised May 7, 2001; accepted May 24, 2001.

This work was supported by National Institutes of Health Grant NS21925. We thank Katrina Rothblum for help with expression of the recombinant $\alpha 4(\mathrm{~V})$ N-terminal domain and Dr. Victor Koteliansky for the generous gift of function blocking anti-integrin antibodies.

Correspondence should be addressed to Dr. David J. Carey, Sigfried and Janet Weis Center for Research, 100 North Academy Avenue, Danville, PA 17822-2613. E-mail: djcarey@geisinger.edu.

Copyright (ㄷ) 2001 Society for Neuroscience $\quad 0270-6474 / 01 / 216125-11 \$ 15.00 / 0$
}

ited by soluble heparin but not by function-blocking antibodies against $\alpha 1$ - and $\alpha 2$-integrins. The collagen domain of pepsindigested collagen type $\mathrm{V}$ was poorly adhesive for Schwann cells. The type $\mathrm{V}$ collagen domain but not the $\alpha 4(\mathrm{~V}) \mathrm{N}$-terminal domain blocked neurite outgrowth from dorsal root ganglion neurons. In cocultures of dorsal root ganglion neurons and Schwann cells, collagen type $\mathrm{V}_{\mathrm{Sc}}$ promoted axon fasciculation and association of axons with Schwann cells. These results suggest that in embryonic peripheral nerves, collagen type $\mathrm{V}_{\mathrm{SC}}$ plays a dual role in regulating cell migration. This represents a heretofore unrecognized function of peripheral nerve collagen fibrils in regulating patterns of peripheral nerve growth during development.

Key words: Schwann cell; axonal outgrowth; extracellular matrix; cell migration; collagen; integrins; heparan sulfate

protein as a member of the type $\mathrm{V}$ collagen family, which we called $\alpha 4(\mathrm{~V})$-collagen (Chernousov et al., 2000). $\alpha 4(\mathrm{~V})$-collagen exhibits several unusual properties that are likely to influence its biological function. This collagen chain binds the heparan sulfate proteoglycan syndecan 3 with high affinity $\left(K_{\mathrm{d}}, \sim 0.2 \mathrm{~nm}\right)$ through an interaction with the proteoglycan heparan sulfate chains (Chernousov et al., 1996). In contrast to other fibril-forming collagens, type $\mathrm{V}$ collagens often retain their $\mathrm{N}$-terminal noncollagenous domains (Linsenmayer et al., 1993; Moradi-Ameli et al., 1994). This occurs to a high degree for $\alpha 4(\mathrm{~V})$-collagen chains synthesized by Schwann cells and in developing peripheral nerves in vivo (Chernousov et al., 2000).

During the period in which $\alpha 4(\mathrm{~V})$-containing collagen molecules are expressed by Schwann cells, the nerves are in a dynamic state of axonal growth and Schwann cell proliferation and migration (Webster et al., 1973). Many ECM proteins, including some collagens, promote the outgrowth of axons from cultured neurons (Hynes and Lander, 1992), as well as migration of Schwann cells. Thus, ECM molecules might function as contact-dependent guidance cues. Contact-dependent repulsive signals also provide important cues that direct nerve fiber growth (Tessier-Lavigne and Goodman, 1996). Such functions have also been ascribed to some ECM proteins, notably tenascin (Gotz et al., 1996), particular laminin isoforms (Patton et al., 1997), and chondroitin sulfate proteoglycans (Dou and Levine, 1995; Brittis et al., 1995; Zuo et al., 1998).

The restricted pattern of expression and unusual biochemical properties suggest that $\alpha 4(\mathrm{~V})$-containing collagen molecules might perform important functions in developing nerves. This paper presents our findings on adhesion and migration-promoting activities of Schwann cell type $\mathrm{V}$ collagen. The results demon- 
strate that Schwann cell type $\mathrm{V}$ collagen is multifunctional and displays domain-specific effects on axonal outgrowth and Schwann cell adhesion.

\section{MATERIALS AND METHODS}

Purification of Schwann cell collagen type V. Collagen type V was isolated from cultures of neonatal rat Schwann cells as described previously (Chernousov et al., 2000). Briefly, conditioned medium of ascorbatetreated Schwann cells was collected and fractionated by salt precipitation, anion exchange chromatography, and heparin affinity chromatography. The elution of collagen type $\mathrm{V}$ was monitored by immunoblot analysis using antibodies specific for the $\alpha 4(\mathrm{~V})$-collagen subunit (previously called p200). The purity of the final preparation was verified by SDSPAGE and silver staining. Pepsinized bovine placenta type V collagen was obtained from Chemicon (Temecula, CA).

Preparation of the recombinant $\alpha 4(V) N$-terminal domain. The noncollagenous N-terminal domain (NTD) of $\alpha 4(\mathrm{~V})$-collagen was expressed as a His-tagged recombinant protein in bacterial cells. The cDNA coding for this domain (corresponding to amino acids 30-369; Chernousov et al., 2000) was generated by PCR amplification using sequence-specific primers and full-length $\alpha 4(\mathrm{~V})$ cDNA as the template. The cDNA product was subcloned into plasmid pET30-a ${ }^{+}$(Novagen, Madison, WI) for transformation and induction of expression in Escherichia coli cells (strain BL21-pLysS). The recombinant protein was purified from cell lysates by $\mathrm{Ni}^{2+}$ affinity chromatography. Purity of the final product was verified by SDS-PAGE.

Schwann cell migration assay. Multiwell plastic dishes (4-well, Nunc, Naperville, IL; or 12-well, Corning, Corning, NY) were coated with purified ECM proteins $(10 \mu \mathrm{g} / \mathrm{ml}$ in $50 \mathrm{~mm}$ Tris- $\mathrm{HCl}, \mathrm{pH} 7.5$, and $0.1 \mathrm{M}$ $\mathrm{NaCl}$ ) overnight at $37^{\circ} \mathrm{C}$ at a coating density of $2 \mu \mathrm{g} / \mathrm{cm}^{2}$. The protein solution was removed by aspiration, and the wells were rinsed with water and air-dried.

Dorsal root ganglia were dissected from 18-d-gestation rat embryos. The capsules were removed, and the ganglia were placed onto the coated dishes and covered with $\sim 50 \mu \mathrm{l}$ of serum-free medium. The medium consisted of a 1:1 mixture of DMEM and Ham's F-12 medium supplemented with $100 \mu \mathrm{g} / \mathrm{ml}$ apotransferrin, $5 \mu \mathrm{g} / \mathrm{ml}$ insulin, $1.4 \mathrm{~mm}$ L-glutamine, $200 \mathrm{~nm}$ progesterone, $100 \mu \mathrm{m}$ of putrescine, $30 \mathrm{~nm}$ selenium, and $250 \mathrm{ng} / \mathrm{ml}$ heregulin peptide (Rahmatullah et al., 1998). Heregulin was added to the medium to promote Schwann cell survival and differentiation (Grinspan et al., 1996; Syroid et al., 1996). Heregulins also have been shown to stimulate Schwann cell migration (Mahanthappa et al., 1996). The ganglia were incubated at $37^{\circ} \mathrm{C}$ in a humidified tissue culture incubator in at atmosphere of $7 \% \mathrm{CO}_{2}$. On the following day, sufficient medium was added to cover the bottoms of the culture wells, and the incubation was continued. Schwann cells that migrated from the ganglia were visualized by phase contrast microscopy and photographed. Migration was quantitated by measuring the distance on photomicrographs from the edge of a ganglion to the leading edge of migrating Schwann cells, i.e., the cohort of cells that had migrated the greatest distance from the ganglion. Three measurements were made in different directions of radial migration for each ganglion and averaged. Collagen type I was obtained from Collaborative Biomedical Products. Collagen type IV was from Becton Dickinson (Mountain View, CA). Laminin (mouse EHS) was from Sigma (St. Louis, MO). Human plasma fibronectin was purchased from Chemicon.

Neurite outgrowth assays. Neurite outgrowth assays were similar to the Schwann cell migration assays, except that the serum-free medium contained nerve growth factor in place of heregulin peptide. In some experiments the ganglia were dissociated to single-cell suspensions before plating onto ECM-coated dishes. Ganglia were dissociated by incubation for $30 \mathrm{~min}$ in $0.05 \%$ trypsin in calcium- and magnesium-free HBSS and trituration through a small-bore pipette. Trypsin activity was stopped by addition of soybean trypsin inhibitor $(0.05 \%)$.

Assays to determine the effects of combinations of ECM proteins were performed as follows. Dishes were first coated with a single purified ECM protein as described above. The following day, $\sim 50 \mu \mathrm{l}$ of a second ECM protein $(10 \mu \mathrm{g} / \mathrm{ml})$ was applied as a single drop to the center of the dry well. The dishes were incubated for $2 \mathrm{hr}$ at $37^{\circ} \mathrm{C}$. The solution was removed, and the wells were rinsed with water and air dried. This procedure produces an area in which the dish is coated with an approximately equimolar ratio of the two ECM proteins. Dorsal root ganglia were placed on these dishes and incubated for up to $4 \mathrm{~d}$. Outgrowth of axons was visualized and quantitated as described above.
A

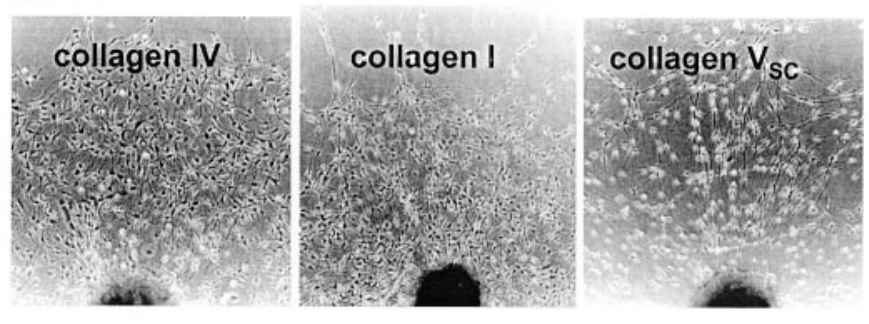

B
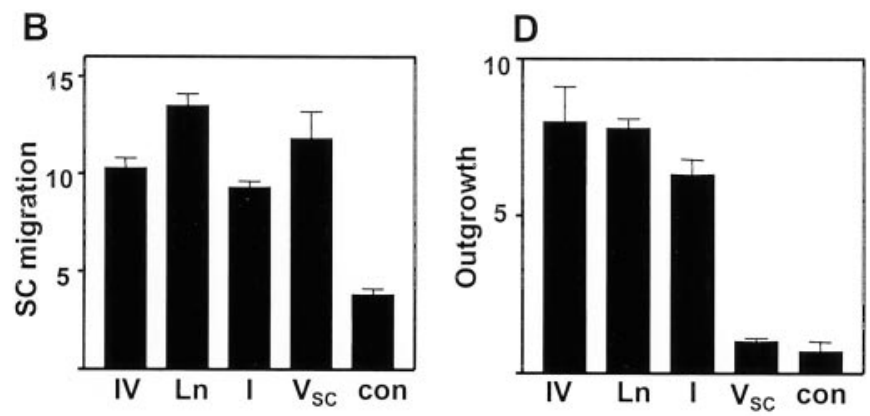

C
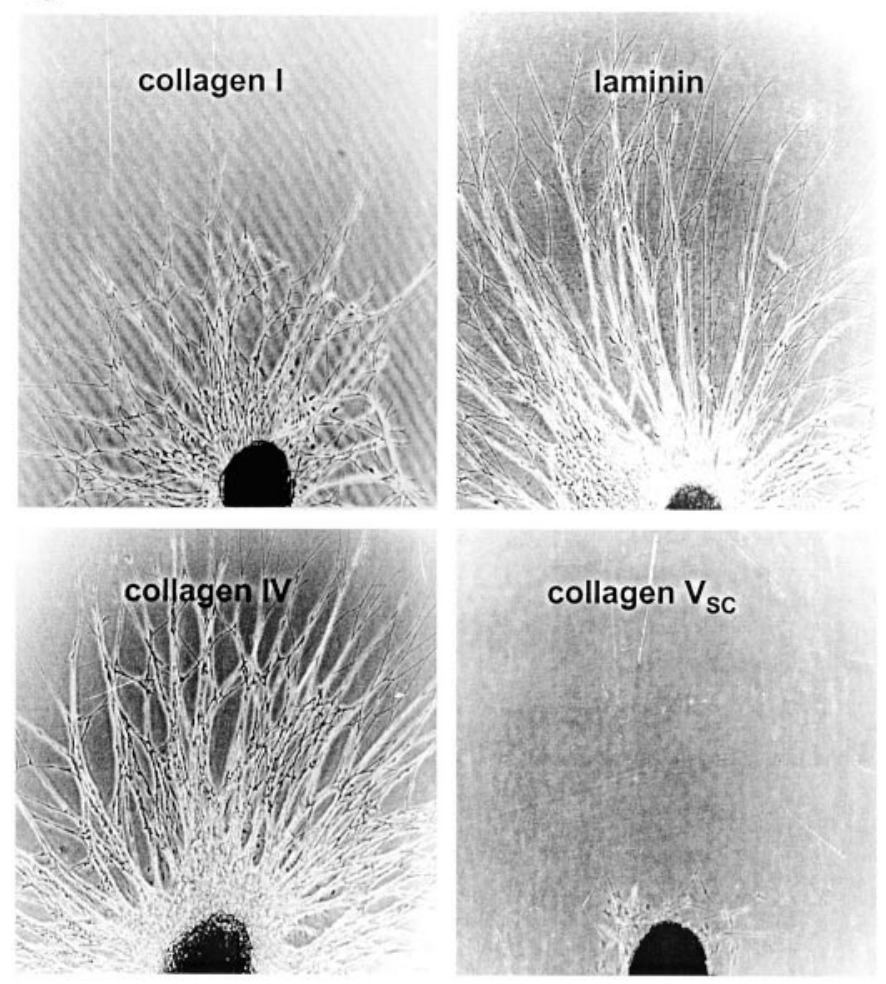

Figure 1. Schwann cell migration and axonal outgrowth on ECM-coated surfaces. $A$, Rat embryo dorsal root ganglia were cultured in serum-free medium with heregulin on dishes coated with the indicated ECM proteins. The ganglia were incubated for $4 \mathrm{~d}$ and examined by phase contrast microscopy. $B$, Schwann cell migration was quantitated as described in Materials and Methods, and the results are displayed graphically. The values shown are the mean $\pm \mathrm{SD}$ for measurements made on four separate cultures. $C$, Rat embryo dorsal root ganglia were cultured on dishes coated with the indicated ECM proteins in serum free medium with nerve growth factor. The micrographs show outgrowth from individual ganglia after $4 \mathrm{~d}$ in culture. $D$, Axonal outgrowth was quantitated after $4 \mathrm{~d}$ in culture, and the results are shown graphically. The values shown are the mean \pm SD for measurements made on four separate cultures. $I V$, Collagen type IV; $L n$, laminin; $I$, collagen type I; $V_{S C}$, collagen type $\mathrm{V}_{\mathrm{SC}}$; con, control (uncoated plastic). 
Schwann cell adhesion assays. Twenty-four-well plates were coated with ECM proteins $(20 \mu \mathrm{g} / \mathrm{ml}$ in $20 \mathrm{~mm}$ Tris- $\mathrm{HCl}, \mathrm{pH} 7.6$, and $0.1 \mathrm{M} \mathrm{NaCl})$ at a coating density of $2 \mu \mathrm{g} / \mathrm{cm}^{2}$ overnight at $37^{\circ} \mathrm{C}$. After removing the protein solution and washing with Tris buffer, the dishes were blocked with $1 \%$ BSA in Tris buffer for $1 \mathrm{hr}$ at $37^{\circ} \mathrm{C}$. Schwann cells were isolated from newborn rat sciatic nerves and cultured in DMEM, $10 \%$ fetal bovine serum, and $2 \mu \mathrm{M}$ forskolin as described previously (Carey and Stahl, 1990). For adhesion assays, Schwann cells were released by trypsinization and resuspended in serum-free medium with heregulin. The cells were added to the ECM-coated wells and incubated for $3 \mathrm{hr}$ at $37^{\circ} \mathrm{C}$. In some experiments, inhibitors of cell adhesion were used. Function-blocking hamster monoclonal anti-integrin $\alpha 1$ (clone Ha31/8) and anti-integrin $\alpha 2$ (clone Ha1/29) antibodies were obtained from Dr. Victor Koteliansky (Biogen, Cambridge, MA). Function-blocking hamster monoclonal anti- $\beta 1$-integrin antibody (clone Ha2/5) was purchased from PharMingen (San Diego, CA). These antibodies or a control hamster monoclonal antibody was added to the attachment medium at a concentration of $10 \mu \mathrm{g} / \mathrm{ml}$. Heparin $(10 \mu \mathrm{g} / \mathrm{ml})$ was also used as a competitive inhibitor of heparan sulfate-dependent binding interactions. At the end of the incubation period, the medium was aspirated, and the wells were washed with DMEM to remove nonadherent cells. Attached cells were fixed with 3\% paraformaldehyde in PBS and stained with $0.5 \%$ crystal violet in $10 \%$ ethanol for $20 \mathrm{~min}$. After extensive washing with water, bound dye was solubilized with $1 \%$ SDS, and the absorbance was read at a wavelength of $595 \mathrm{~nm}$. All adhesion experiments were done in duplicate and repeated at least two times.

Experiments to investigate Schwann cell spreading were performed in the same way, except that the cells were incubated for $24 \mathrm{hr}$. Cell spreading was visualized by phase contrast microscopy.

Immunofluorescence microscopy. Immunofluorescent staining of cultured Schwann cells and neurons was performed as described previously (Carey and Stahl, 1990). Mouse monoclonal anti-neurofilament antibody and goat anti-mouse IgG coupled to fluorescein isothiocyanate was obtained from Sigma. Rabbit anti-S100 antibodies were from Dako (Glostrup, Denmark). Goat anti-rabbit IgG conjugated with Texas Red-X was obtained from Molecular Probes (Eugene, OR).

\section{RESULTS}

\section{Type V collagen synthesized by Schwann cells promotes Schwann cell migration}

Type V collagen was purified from conditioned medium of ascorbate-treated Schwann cells. As described previously, type V collagen synthesized by Schwann cells (collagen type $\mathrm{V}_{\mathrm{SC}}$ ) is a heterotrimer that contains $\alpha 4(\mathrm{~V})$ and $\alpha 1(\mathrm{~V})$ collagen chains (Chernousov et al., 2000). The ability of collagen type $\mathrm{V}_{\mathrm{SC}}$ to promote Schwann cell migration was investigated and compared with the activities of other ECM proteins that are also present in the peripheral nerve ECM. For these experiments, rat embryo dorsal root ganglia were placed on ECM-coated plastic dishes and cultured in serum-free medium that lacked neurotrophic agents but contained heregulin, a growth factor that promotes Schwann cell survival and differentiation (Grinspan et al., 1996; Syroid et al., 1996). Under these conditions, outgrowth of axons from the ganglia was not observed on any substrate. Schwann cells migrated from ganglia cultured on collagen type I, collagen type $\mathrm{IV}$, collagen type $\mathrm{V}_{\mathrm{SC}}$ (Fig. $1 A$ ), and laminin (data not shown). Identification of the migrating cells as Schwann cells was confirmed by staining with the cell-specific marker S100 (data not shown). Quantitation of Schwann cell migration revealed that the collagens and laminin were significantly better at stimulating migration than control substrata (Fig. 1B).

\section{Collagen type $\mathbf{V}_{\mathbf{s c}}$ inhibits axonal outgrowth}

The ability of collagen type $\mathrm{V}_{\mathrm{SC}}$ to promote outgrowth of axons from rat embryo sensory neurons was also examined and compared with outgrowth-promoting activities of other ECM proteins. For these experiments, rat embryo dorsal root ganglia were placed on plastic dishes coated with matrix proteins and cultured
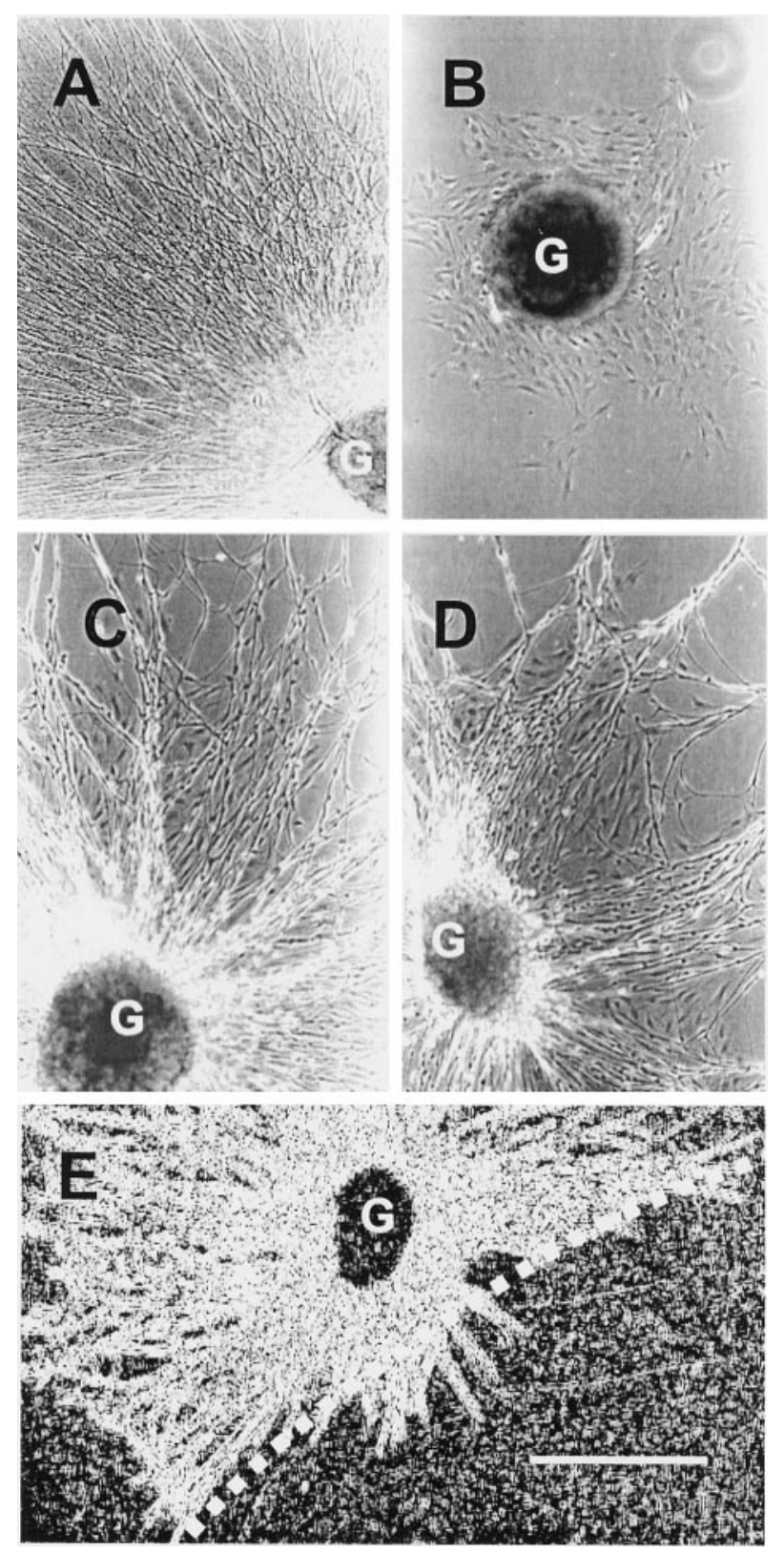

Figure 2. Inhibition of axonal outgrowth by collagen type $\mathrm{V}_{\mathrm{SC}}$. Dishes were coated with collagen type IV, and then a part of each dish was also coated with collagen type $\mathrm{V}_{\mathrm{SC}}(B, E)$ or collagen type $\mathrm{I}(D)$. Rat embryo dorsal root ganglia were cultured on these dishes for $4 \mathrm{~d}$ in serum-free medium with nerve growth factor. $A$, Outgrowth from a ganglion $(G)$ placed on a region that contained only collagen type IV. Only a portion of the radial outgrowth is shown. $B$, Lack of outgrowth from a ganglion placed on a region that contained both collagen type IV and collagen type $\mathrm{V}_{\mathrm{SC}}$. $C, D$, Outgrowth from ganglia placed on regions containing only collagen type IV $(C)$ or both collagen type IV and collagen type I $(D) . E$, Ganglia placed near the border generated axonal outgrowth into areas that contained only collagen type IV (left of dashed line) but not into areas that contained both collagen type IV and collagen type $\mathrm{V}_{\mathrm{SC}}$ (right). This image was enhanced to better display the axonal outgrowth. Scale bar, $500 \mu \mathrm{m}$.

in serum-free medium that contained nerve growth factor. On dishes coated with laminin, collagen type I, or collagen type IV, the ganglia produced dense radial outgrowths of axons (Fig. 1C). The axonal nature of these processes was confirmed by staining with anti-neurofilament antibodies (data not shown). In contrast, ganglia plated on dishes coated with collagen type $\mathrm{V}_{\mathrm{SC}}$ failed to 
A

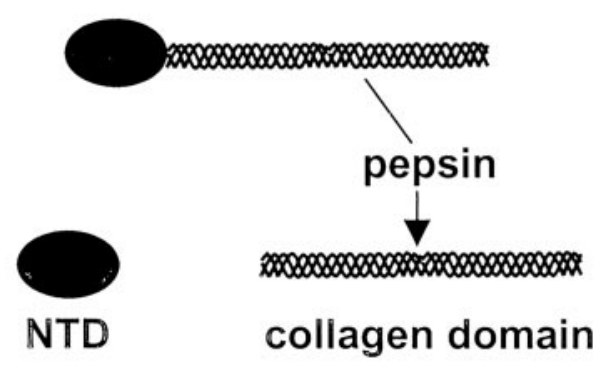

C

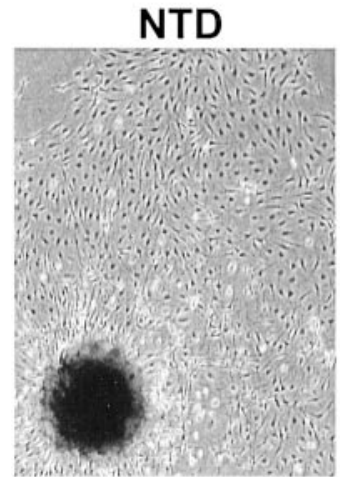

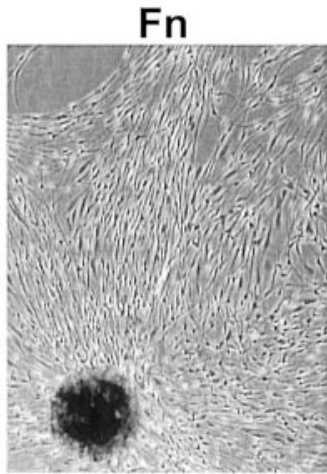

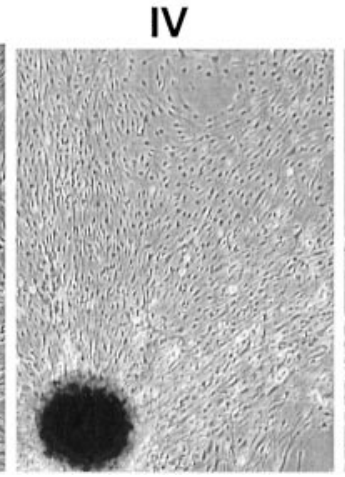

B

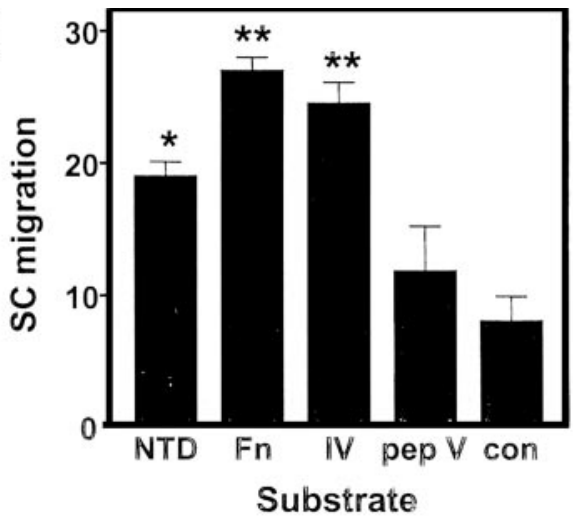

Figure 3. Effects of the $\alpha 4(\mathrm{~V})$ NTD and collagen domain of type V collagen on Schwann cell migration. $A$, Diagram illustrating the proposed domain structure of collagen type $\mathrm{V}_{\mathrm{SC}} \cdot B$, Rat embryo dorsal root ganglia were plated on dishes coated with the indicated proteins and cultured for $4 \mathrm{~d}$ in serum-free medium with heregulin. Schwann cell $(S C)$ migration was quantitated as described in Materials and Methods. Data shown are mean \pm SD of measurements made on four ganglia. *Values that are significantly different from control values. $C$, Schwann cell migration from dorsal root ganglion explants was visualized by phase contrast microscopy. Fn, Fibronectin; $I V$, collagen type IV; pep V, pepsinized collagen type V; con, control dishes (uncoated plastic).

produce significant outgrowth of axons (Fig. 1C). Quantitation of axonal outgrowth is shown in Figure $1 D$. Dishes coated with laminin, collagen type I, or collagen type IV produced outgrowths that were significantly longer than control dishes. In contrast, axonal outgrowth on collagen type $\mathrm{V}_{\mathrm{SC}}$-coated dishes was indistinguishable from that of controls.

To determine whether collagen type $\mathrm{V}_{\mathrm{SC}}$ actively inhibited axonal outgrowth, the effects of combinations of collagen type $\mathrm{V}_{\mathrm{SC}}$ and an active substratum were examined. Composite substrata were prepared in which different regions of the same culture dish were coated with an outgrowth-promoting protein (e.g., collagen type IV) or with the outgrowth-promoting protein and collagen type $\mathrm{V}_{\mathrm{SC}}$. As shown in Figure $2 A$, ganglia placed on regions coated with collagen type IV produced robust axonal outgrowth. Within the same culture dish, ganglia placed on regions that also contained collagen type $\mathrm{V}_{\mathrm{SC}}$ failed to produce axonal outgrowth (Fig. $2 B$ ). In contrast to the effect on axonal outgrowth, migration of non-neuronal cells from the ganglia was observed on the composite substrata. Similar results were obtained when laminin was used in place of collagen type IV (data not shown). When collagen type $\mathrm{V}_{\mathrm{SC}}$ was replaced in this assay by the active substrate collagen type I, similar levels of axonal outgrowth were observed in the singly or doubly coated areas of the dishes (Fig. 2C,D), demonstrating that the coating method did not inhibit axonal outgrowth. When ganglia were placed on a collagen type IV substratum adjacent to an area that also contained collagen type $\mathrm{V}_{\mathrm{SC}}$, axonal outgrowth was observed into the area lacking the latter collagen. In contrast, axons failed to extend into the region that contained collagen type $\mathrm{V}_{\mathrm{SC}}$, despite the presence of the outgrowth-promoting ECM protein (Fig. 2E). Together, these results demonstrate that collagen type $V_{\text {SC }}$ inhibits axonal outgrowth.

\section{Domain-specific adhesive functions of collagen type $\mathbf{V}$}

Collagen type $\mathrm{V}_{\mathrm{SC}}$ contains a large collagen triple-helical domain and an N-terminal noncollagenous domain (Chernousov et al., 2000) (Fig. 3A). A series of experiments were performed to determine which of these domains mediated the effects of collagen type $\mathrm{V}_{\mathrm{SC}}$ on Schwann cell migration and axonal outgrowth. The NTD of collagen $\alpha 4(\mathrm{~V})$ was expressed as a recombinant His-tagged protein. Efforts to express the collagen domain in the native triple-helical conformation were unsuccessful. Because of the low yield of purified collagen type $V$ from Schwann cells, the collagen domain of pepsin-digested bovine type $\mathrm{V}$ collagen was used for these experiments.

\section{Schwann cell migration}

The ability of the $\alpha 4(\mathrm{~V})$ NTD and type V collagen domain to induce Schwann cell migration was examined. Schwann cells migrated from dorsal root ganglion explants on dishes coated with the NTD, fibronectin, or collagen type IV (Fig. 3B,C). Migration of Schwann cells on dishes coated with pepsin-digested type $\mathrm{V}$ collagen was only slightly better than migration on control dishes. The cells migrating on the NTD were well spread, similar 


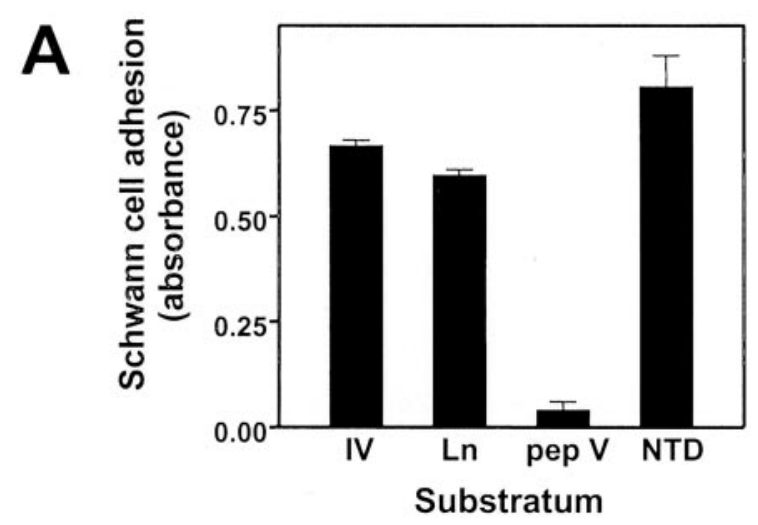

B
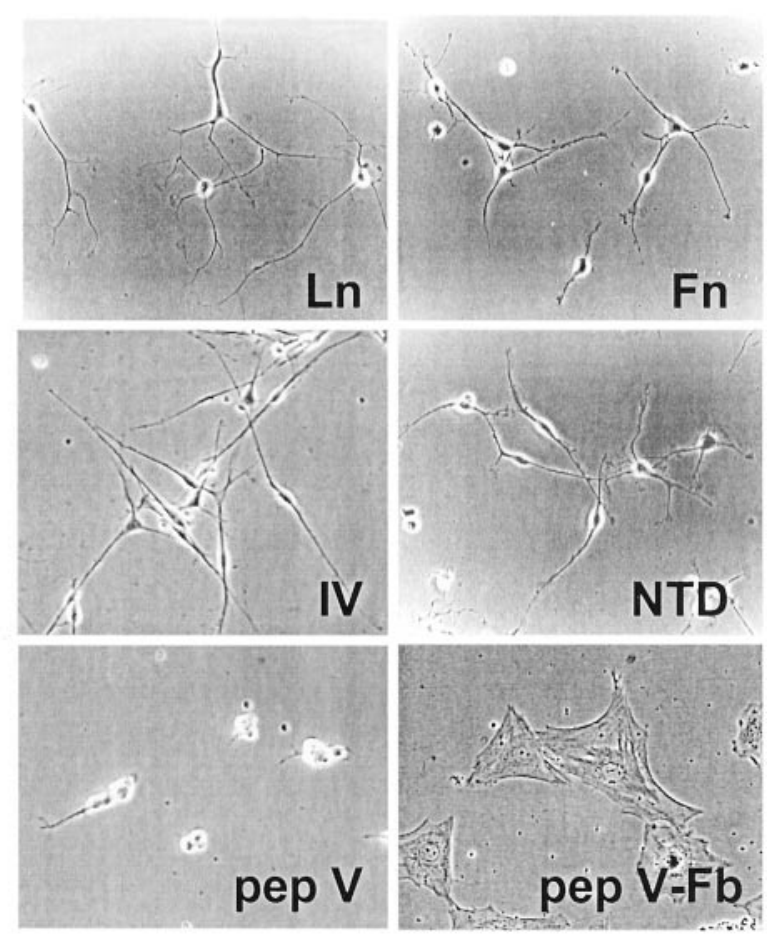

Figure 4. Schwann cell adhesion and spreading on ECM proteins. $A$, Schwann cells were plated on dishes coated with the indicated ECM proteins and incubated in serum-free medium with heregulin. Schwann cell adhesion was measured after $3 \mathrm{hr}$ using the crystal violet assay. Values shown are mean $\pm \mathrm{SD}$ for three separate measurements. $B$, Schwann cells or fetal rat fibroblasts were plated on dishes coated with the indicated ECM proteins and incubated in serum-free medium with heregulin. Schwann cell spreading was monitored by phase contrast microscopy. $L n$, Laminin; $F n$, fibronectin; $I V$, collagen type IV; pep $V$, pepsinized collagen type $\mathrm{V}$; pep $V-F b$, rat embryo fibroblasts plated on pepsinized type $\mathrm{V}$ collagen.

to what was observed on fibronectin or collagen type IV. In contrast, Schwann cells migrating on pepsin-digested collagen type $\mathrm{V}$ or control dishes were not well spread (Fig. 3C). These results demonstrate that the NTD but not the collagen domain promotes Schwann cell migration.

\section{Schwann cell adhesion and spreading}

To investigate the Schwann cell-collagen type $\mathrm{V}$ interaction further, Schwann cell adhesion to ECM-coated dishes was measured using a dye-based assay. As shown in Figure $4 A$, in this short-term assay ( $3 \mathrm{hr}$ ), Schwann cells adhered to the ECM proteins collagen type IV and laminin and to the $\alpha 4(\mathrm{~V})$ NTD but failed to adhere to pepsinized type $\mathrm{V}$ collagen.
Schwann cell spreading was examined after overnight incubation on ECM-coated dishes. Schwann cells spread extensively on the ECM proteins laminin, fibronectin, and collagen type IV as well as on the $\alpha 4$ (V) NTD (Fig. 4B). On these adhesive substrata, Schwann cells extended thin processes that terminated in flattened lamellopodia. Although some adhesion to the collagen domain of pepsinized type $\mathrm{V}$ collagen was evident in this assay, Schwann cells failed to spread or to extend processes. In contrast, fetal rat fibroblasts adhered to and spread normally on pepsinized type V collagen (Fig. 4B). Together, these results support the conclusion that the primary adhesive interaction between Schwann cells and collagen type $\mathrm{V}$ is through the noncollagenous N-terminal domain.

To explore the mechanism of Schwann cell adhesion to the NTD, receptor-specific inhibitors were used. For comparison, the effects of these inhibitors on adhesion to collagen type IV were also determined. The best-characterized cellular receptors for collagen molecules are $\alpha 1 \beta 1$ - and $\alpha 2 \beta 1$-integrins (Dickeson et al., 1999; Knight et al., 2000; Nykvist et al., 2000), which are expressed by Schwann cells (Hsiao et al., 1991; Milner et al., 1997). The function-blocking monoclonal anti- $\alpha 1$-integrin antibody inhibited Schwann cell adhesion to collagen type IV by $\sim 50 \%$ (Fig. $5 A$ ). The anti- $\alpha 2$-integrin antibody alone produced only a small inhibition, but the anti- $\alpha 1$ and anti- $\alpha 2$ antibodies together inhibited adhesion to collagen IV by $\sim 80 \%$. The anti- $\beta 1$-integrin antibody inhibited Schwann cell adhesion to collagen type IV by $72 \%$. The glycosaminoglycan heparin produced only a modest inhibition of Schwann cell adhesion to collagen IV. In contrast to these results, Schwann cell adhesion to the NTD was not significantly inhibited by the anti- $\alpha 1$ - or $-\alpha 2$-integrin antibodies (Fig. $5 A$ ) and was only modestly inhibited by the anti- $\beta 1$-integrin antibody (Fig. 5B). Schwann cell adhesion to the NTD was inhibited almost completely, however, by heparin (Fig. 5A,B). These results suggest that Schwann cells adhere to collagen type IV primarily by an $\alpha 1 \beta 1$-integrin-dependent mechanism and to the NTD by a different mechanism.

This conclusion was further supported by experiments that examined the effects of the inhibitors on Schwann cell spreading. As shown in Figure 5C, Schwann cell spreading on collagen type IV was blocked by the anti- $\alpha 1$-integrin antibody, whereas the anti- $\alpha 2$ integrin antibody and heparin had little effect. In contrast, Schwann cell spreading on the NTD was blocked completely by heparin but was not affected by the anti-integrin antibodies (Fig. 5C).

In light of the inhibitory effect of collagen type $\mathrm{V}_{\mathrm{SC}}$ on neurite outgrowth described above, an experiment was performed to determine whether either the NTD or the collagen domain of collagen type V inhibited Schwann cell adhesion. Schwann cell adhesion to collagen type IV or laminin was measured in the absence or presence of pepsinized collagen V or the NTD. As shown in Figure 6, pepsinized type $\mathrm{V}$ collagen partially inhibited adhesion to collagen type IV (35\% inhibition) or laminin $(36 \%$ inhibition). The presence of the NTD produced a slight increase in adhesion to dishes coated with collagen type IV or laminin. The collagen domain failed to significantly inhibit adhesion of Schwann cells to the NTD (Fig. 6).

\section{Neurite outgrowth}

To identify the domain of collagen type $\mathrm{V}_{\mathrm{SC}}$ responsible for inhibition of neurite outgrowth, rat embryo dorsal root ganglia were plated on dishes coated with combinations of collagen type IV and the NTD or pepsin-digested type V collagen. As shown in 
A

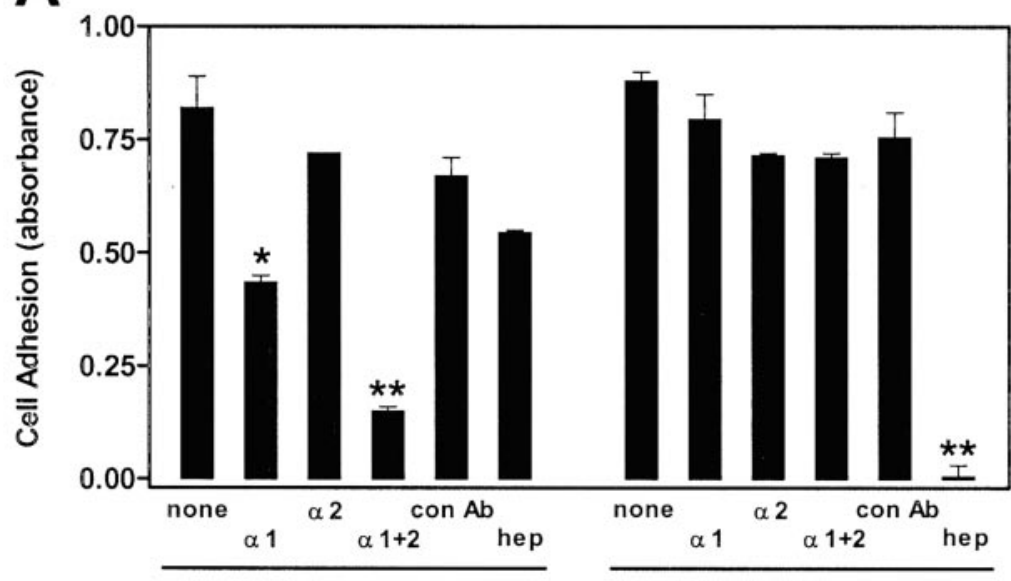

substrate: collagen IV

substrate: NTD
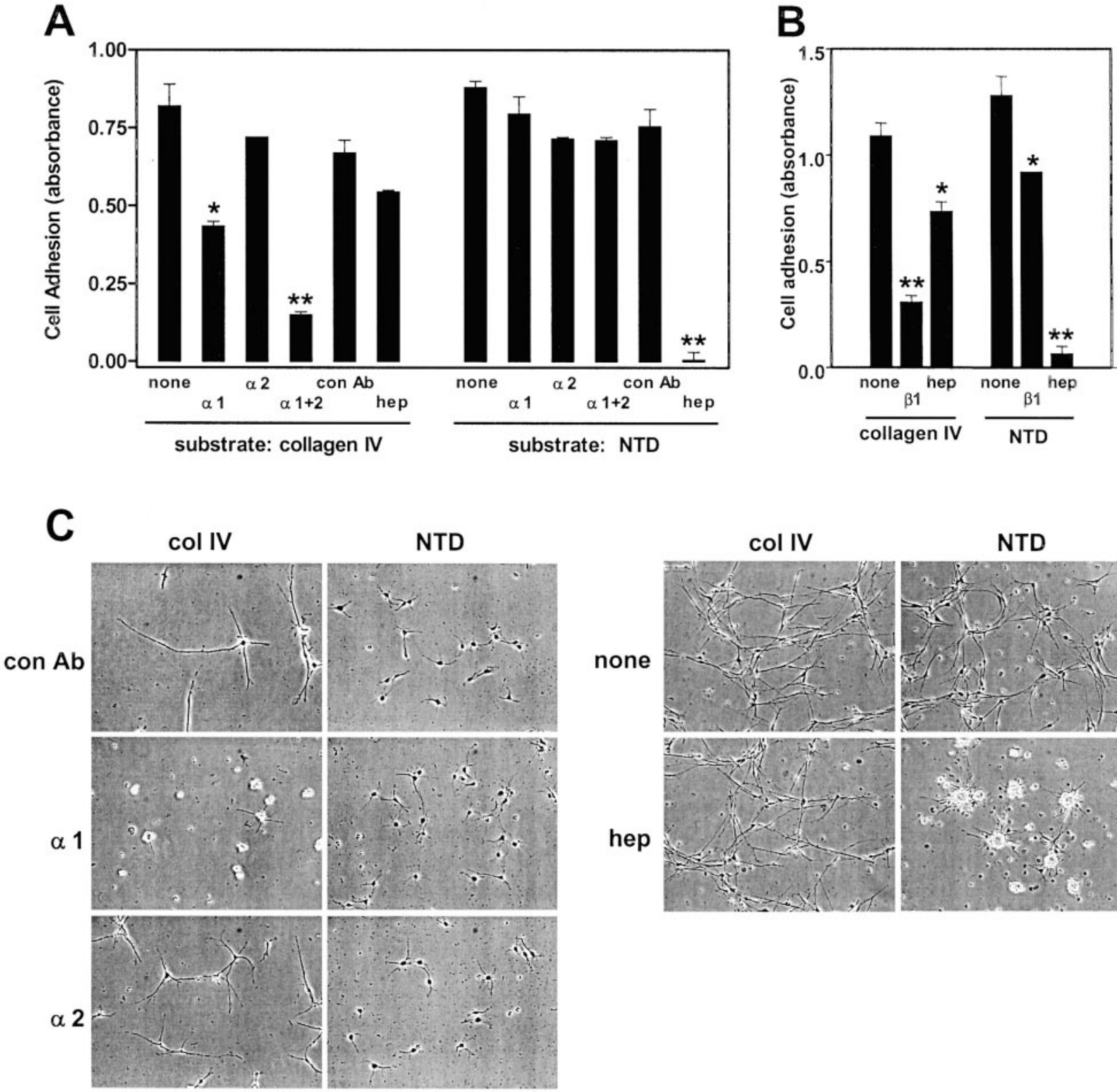
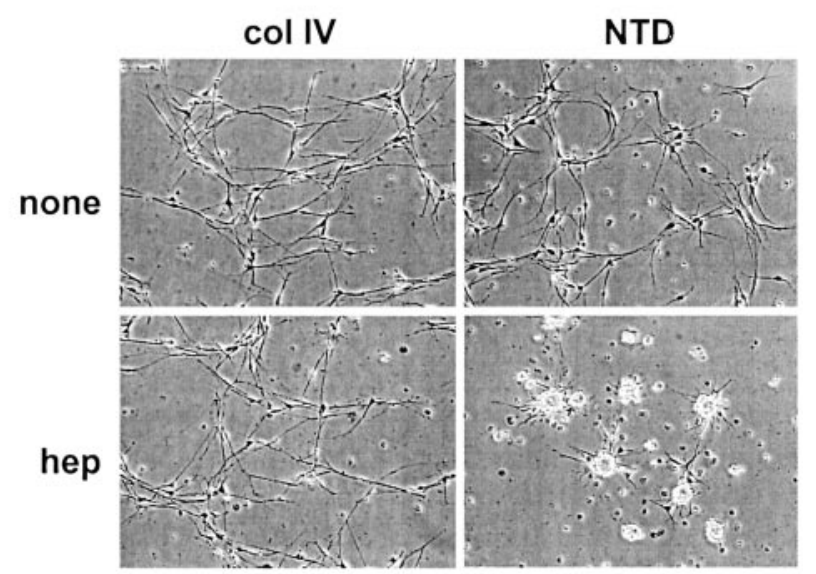

Figure 5. Inhibition of Schwann cell adhesion and spreading on collagen type IV and $\alpha 4(\mathrm{~V})$ NTD. $A, B$, Schwann cells were plated on dishes coated with collagen type IV or $\alpha 4(\mathrm{~V})$ NTD and incubated for $3 \mathrm{hr}$ in serum-free medium with heregulin alone or in medium with the anti- $\alpha 1$-integrin antibody $(\alpha 1)$, the anti- $\alpha 2$-integrin antibody $(\alpha 2)$, both antibodies $(\alpha 1+2)$, the anti- $\beta 1$-integrin antibody $(\beta 1)$, a control hamster monoclonal antibody $($ con $A b)$, or $10 \mu \mathrm{g} / \mathrm{ml}$ heparin (hep). Adhesion was measured by the crystal violet assay. Values that were significantly different from controls are indicated $\left({ }^{*} p<\right.$ $0.05 ; * *<0.01)$. $C$, Schwann cells were plated on dishes coated with collagen type IV (col IV) or the $\alpha 4(\mathrm{~V})$ NTD and incubated for 24 hr in serum-free medium with heregulin alone or in medium with the anti- $\alpha 1$-integrin antibody $(\alpha 1)$, the anti- $\alpha 2$ integrin antibody $(\alpha 2)$, a control hamster monoclonal antibody (con $A b$ ), or $10 \mu \mathrm{g} / \mathrm{ml}$ heparin (hep). Schwann cell spreading was monitored by phase contrast microscopy. The micrographs from the left and right sets of panels were from different experiments.

Figure $7 A$, in serum-free medium with nerve growth factor, the neurons produced a dense radial outgrowth on collagen type IV. Addition of the NTD to collagen type IV-coated dishes produced a moderate but statistically significant increase in axonal outgrowth. In contrast, addition of either collagen type $\mathrm{V}_{\mathrm{SC}}$ or pepsin-digested collagen type $\mathrm{V}$ to collagen type IV-coated dishes caused essentially complete inhibition of neurite outgrowth. These results demonstrate that the collagen domain is responsible for the collagen type $\mathrm{V}_{\mathrm{SC}}$-dependent inhibition of neurite outgrowth. On dishes coated with the NTD alone, extensive neurite outgrowth was observed (Fig. 7B). The NTD did not reverse the inhibitory effect of the pepsin-digested collagen domain on neurite outgrowth.

\section{Collagen type $\mathbf{V}_{\mathrm{SC}}$ promotes fasciculation of DRG axons}

The results presented above demonstrate distinct adhesive activities of the noncollagenous NTD and collagen domains of collagen type $\mathrm{V}_{\mathrm{SC}}$. The net effect of these activities on the organization of developing axons and Schwann cells was examined by plating dissociated rat embryo dorsal root ganglion cells, consisting of neurons and Schwann cells, on dishes coated with various 


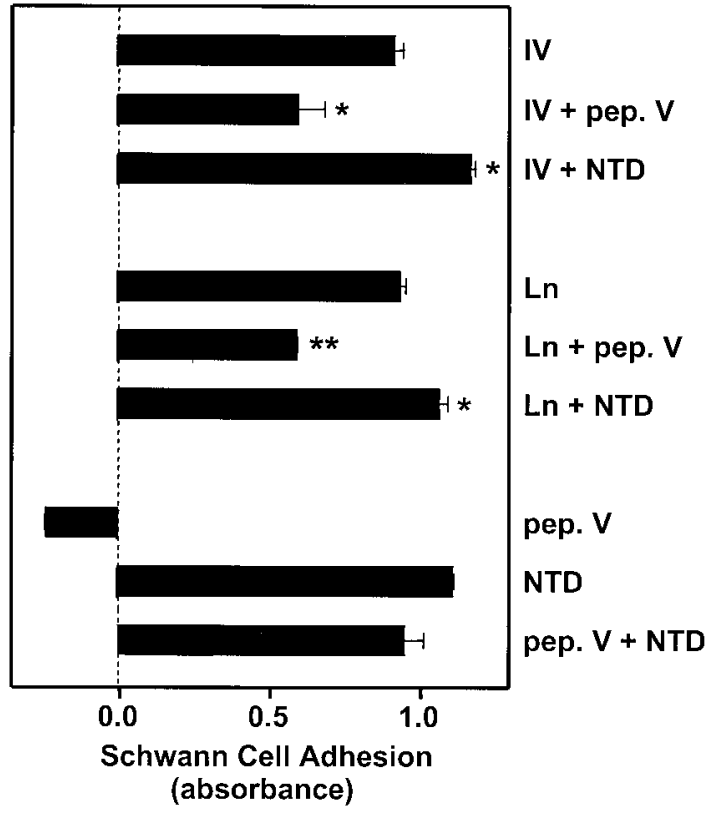

Figure 6. Effect of the $\alpha 4(\mathrm{~V}) \mathrm{NTD}$ and pepsinized collagen type V on Schwann cell adhesion. Schwann cells were plated on dishes coated with the indicated ECM proteins and incubated for $3 \mathrm{hr}$ in serum-free medium with heregulin. Schwann cell adhesion was measured by the crystal violet assay. IV, Collagen type IV; pep. V, pepsinized collagen type V; Ln, laminin. Values that are significantly different from collagen type IV or laminin alone are indicated $\left({ }^{*} p<0.05 ;{ }^{*} p<0.01\right)$. Note that the value for pepsinized collagen type V plus the NTD is not significantly different from that of the NTD alone.

substrata. As shown in Figure 8, when the cells were plated on dishes coated with collagen type IV (Fig. $8 A, E$ ) or collagen type I (Fig. $8 B$ ), the axons produced an apparently random pattern of outgrowth. Some of the axons were associated with Schwann cells, but many were bereft of Schwann cell contact. Essentially identical results were obtained when the dissociated cells were plated on laminin (data not shown). In contrast to these results, when the cells were plated on dishes coated with collagen type $\mathrm{V}_{\mathrm{SC}}$ (Fig. 8C,F) the axon-Schwann cell units were organized into discrete bundles, and all the axons were closely associated with Schwann cells. This pattern of growth more closely replicated the organization displayed by embryonic Schwann cells and axons in vivo.

A similar effect was also observed with dorsal root ganglion explant cultures. Neurites produced by ganglia plated on laminin formed a dense carpet of thin processes (Fig. $8 G$ ) that included both naked axons as well as Schwann cell-associated axons. On laminin-coated dishes, collagen type $\mathrm{V}_{\mathrm{SC}}$ produced a dosedependent inhibition of neurite outgrowth (data not shown). When ganglia were plated on dishes coated with a laminin/ collagen type $\mathrm{V}_{\mathrm{SC}}$ ratio that permitted some axons to emerge, these axons formed larger, discrete bundles that also contained Schwann cells (Fig. 8H).

This effect of collagen type $\mathrm{V}_{\mathrm{SC}}$ was not attributable simply to a lack of strong adhesion. Dissociated dorsal root ganglion cells plated on uncoated plastic dishes (Fig. 8D) produced a pattern of growth that was similar to what was seen on collagen type I or collagen type IV but with fewer total cells.

\section{DISCUSSION}

The peripheral nervous system contains a biochemically complex ECM. Contact with the ECM regulates many aspects of nerve development, including axonal migration, and Schwann cell proliferation and differentiation (Chernousov and Carey, 2000). Previously, we reported the purification, characterization, and cloning of a novel collagen type $\mathrm{V}$ chain, $\alpha 4(\mathrm{~V})$, which is secreted by Schwann cells and binds with high affinity to heparin-like glycosaminoglycans (Chernousov et al., 2000). This polypeptide, which we called p200, was identified initially on the basis of its binding to the heparan sulfate proteoglycan syndecan 3 (Chernousov et al., 1996). The restricted expression of $\alpha 4(\mathrm{~V})$ by Schwann cells during the late embryonic and early postnatal periods (Chernousov et al., 1999) suggested that Schwann cell type V collagen played a role in nerve development.

Collagen type $\mathrm{V}_{\mathrm{SC}}$ appears to have a dual function with respect to Schwann cell and axonal adhesion and migration. This collagen promotes the migration of premyelinating Schwann cells in culture but actively inhibits outgrowth of axons from rat embryo sensory neurons. Collagen type $\mathrm{V}_{\mathrm{SC}}$ blocks the neurite outgrowth-promoting activities of other ECM proteins and prevents the growth of axons into areas where the collagen is present. These activities are mediated by different structural domains of the collagen. The noncollagen NTD promotes Schwann cell adhesion and migration, whereas the triple-helical domain inhibits neurite outgrowth. The latter domain was also poorly adhesive for Schwann cells.

The use of pepsinized placental type $\mathrm{V}$ collagen in these experiments was dictated by our inability to obtain sufficient quantities of either pepsinized collagen type $\mathrm{V}_{\mathrm{SC}}$ from Schwann cells or recombinant collagen domain trimers. Based on biochemical and expression data (Chernousov et al., 1999, 2000), the difference between placental type $\mathrm{V}$ collagen and Schwann cell type $\mathrm{V}$ collagen is the presence of the $\alpha 3$ subunit in placental collagen and the $\alpha 4$ subunit in Schwann cell collagen. Pepsin digestion of these collagens removes the noncollagenous $\mathrm{N}$ - and $\mathrm{C}$-terminal domains, leaving the protease-resistant triple-helical domain. The regions of greatest sequence divergence between the $\alpha 3$ and $\alpha 4$ chains are the noncollagenous domains, especially the N-terminal domains (Chernousov et al., 2000). The triplehelical domains are highly homologous, with $88 \%$ amino acid identity. This structural similarity is supported by our finding that pepsinized placental type $\mathrm{V}$ collagen inhibits neurite outgrowth from dorsal root ganglion neurons in a manner that is indistinguishable from collagen type $\mathrm{V}_{\mathrm{SC}}$. This result strongly suggests that inhibition of neurite outgrowth is caused by the triple-helical collagen domain.

Our results suggest that collagen type $\mathrm{V}_{\mathrm{SC}}$ is a member of the class of inhibitory axonal guidance cues that also includes the netrin and ephrin families of proteins (Tessier-Lavigne and Goodman, 1996). This is in contrast to the activities of many ECM proteins, including most collagens, which promote outgrowth of axons from cultured neurons (McGarvey et al., 1984; Hynes and Lander, 1992; Anton et al., 1994; Milner et al., 1997). Collagen type $\mathrm{V}_{\mathrm{SC}}$ is not the only ECM protein with such inhibitory activity. Chondroitin sulfate proteoglycans isolated from the nervous system (Brittis et al., 1995), tenascin (Gotz et al., 1996), laminin 11 (Patton et al., 1997), and agrin (Campagna et al., 1995) also inhibit axonal outgrowth from different types of neurons. This is the first report of such an activity by a fibrilforming collagen molecule.

The mechanism by which collagen type $\mathrm{V}_{\mathrm{SC}}$ inhibits neurite outgrowth is not known. The fact that inhibition of neurite outgrowth is observed in the presence of an outgrowthpromoting protein suggests that this is an active process. The 


\section{A}
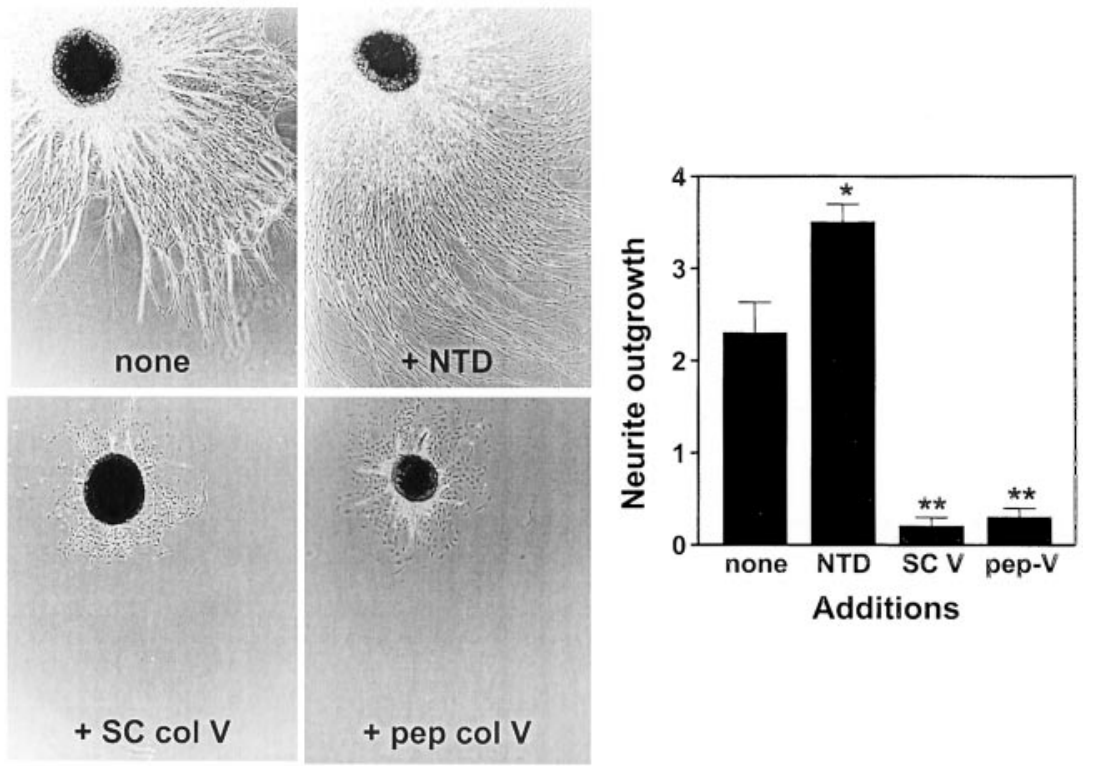

B

Figure 7. Effects of the $\alpha 4(\mathrm{~V})$ NTD and collagen domain of type $\mathrm{V}$ collagen on neurite outgrowth by dorsal root ganglion neurons. $A$, Dorsal root ganglia were placed on dishes coated with collagen type IV and either no additional proteins (none), the NTD, collagen type $\mathrm{V}_{\mathrm{SC}}(+S C \operatorname{col} V)$, or pepsinized type $\mathrm{V}$ collagen $(+$ pep col $V)$. The ganglia were incubated in serum-free medium with nerve growth factor for $4 \mathrm{~d}$. The micrographs show neurite outgrowth, as visualized by phase contrast microscopy, for representative ganglia. Neurite outgrowth was quantitated as described in Materials and Methods, and the results are displayed graphically. Values shown are mean \pm SD for measurements made on four ganglia for each condition. $B$, Dorsal root ganglia were placed on dishes coated with pepsinized collagen type V ( pep col $V$ ), the NTD, or an equimolar ratio of pepsinized collagen type V and NTD. The ganglia were incubated, and neurite outgrowth was measured as for $A$. SC $V$, Collagen type $\mathrm{V}_{\mathrm{SC}}$; pep- $V$, pepsinized collagen type $\mathrm{V}$. Values that differ significantly from controls are indicated $\left({ }^{*} p<0.05 ; * * p<0.005\right)$.
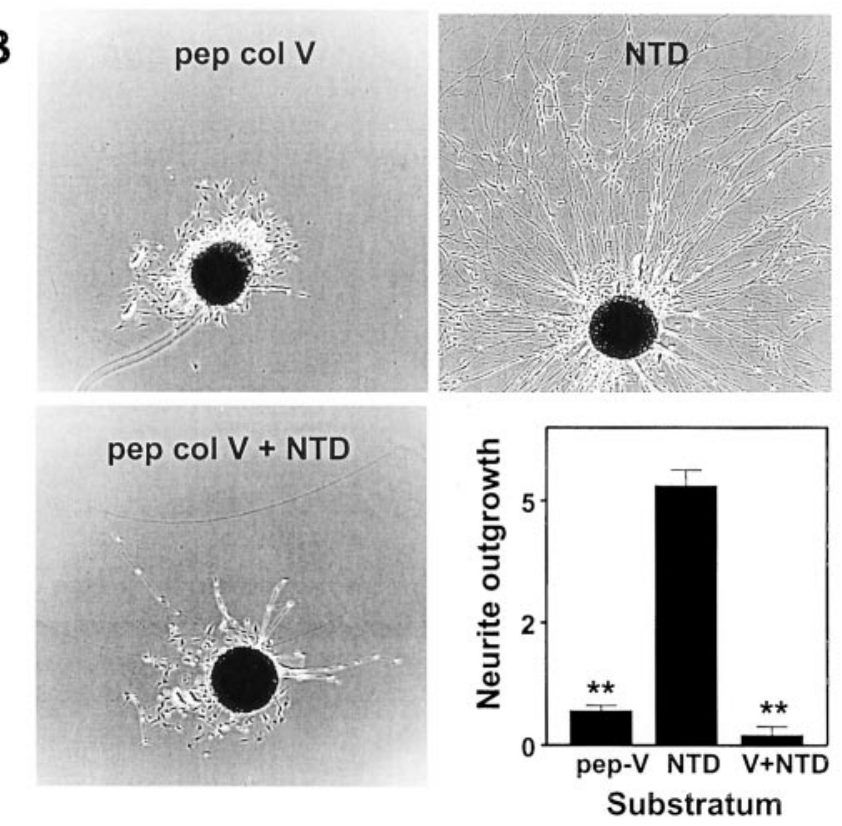

outgrowth-inhibiting activity resides in the triple-helical collagen domain. The triple-helical domains of type V collagens are similar in structure to those of other fibril-forming collagens, such as collagen type I (Prockop and Kivirikko, 1995). The bestcharacterized collagen receptors are $\alpha 1 \beta 1$ - and $\alpha 2 \beta 1$-integrins (Dickeson et al., 1999; Knight et al., 2000). Growth of axons from sympathetic neurons on collagen type IV has been shown to require $\alpha 1 \beta 1$-integrin (Lein et al., 1991). Rat embryo dorsal root ganglion neurons express these integrins. Function-blocking anti$\alpha 1$ - and $\alpha 2$-integrin antibodies inhibit neurite outgrowth by these neurons on collagen type IV (R. C. Stahl, M. A. Chernousov, and D. J. Carey, unpublished observations). $\alpha 1 \beta 1$ - and $\alpha 2 \beta 1$-integrins also bind collagen type V (Nykvist et al., 2000). The different consequences of interaction with collagen type IV and collagen type $\mathrm{V}$ are difficult to reconcile with these observations.

A possible mechanism to explain these findings is that the collagen domain binds other nonintegrin receptors that generate outgrowth-inhibitory signals. The nature of such receptors is unknown, but several candidates can be considered. Most collagens, including type V collagens, bind heparin-like glycosaminoglycans (San Antonio et al., 1994). A heparan sulfate binding site has been localized to the triple-helical domain of collagen type $\mathrm{V}$ (Delacoux et al., 1998). Syndecan transmembrane proteoglycans, which can bind the triple-helical domains of heparin-binding collagens (Sanderson et al., 1994), are present in the growth cones of at least some migrating axons (Raulo et al., 1994; Kinnunen et al., 1996). Syndecans have been shown to modulate kinase activity (Oh et al., 1997; Horowitz and Simons, 1998) and cytoskeletal organization (Carey et al., 1994; Granes et al., 1999) in a variety of cells. Evidence against a role for heparan sulfate proteoglycans comes from the fact that removal of the noncollagen NTD, which contains the high-affinity heparin binding site of the $\alpha 4(\mathrm{~V})$ chain, has no apparent effect on neurite outgrowth inhibition. The collagen domain does influence syndecan-3 binding by $\alpha 4(\mathrm{~V})$, however, because its removal by collagenase treatment lowers the apparent binding affinity for the proteoglycan (Chernousov et al., 

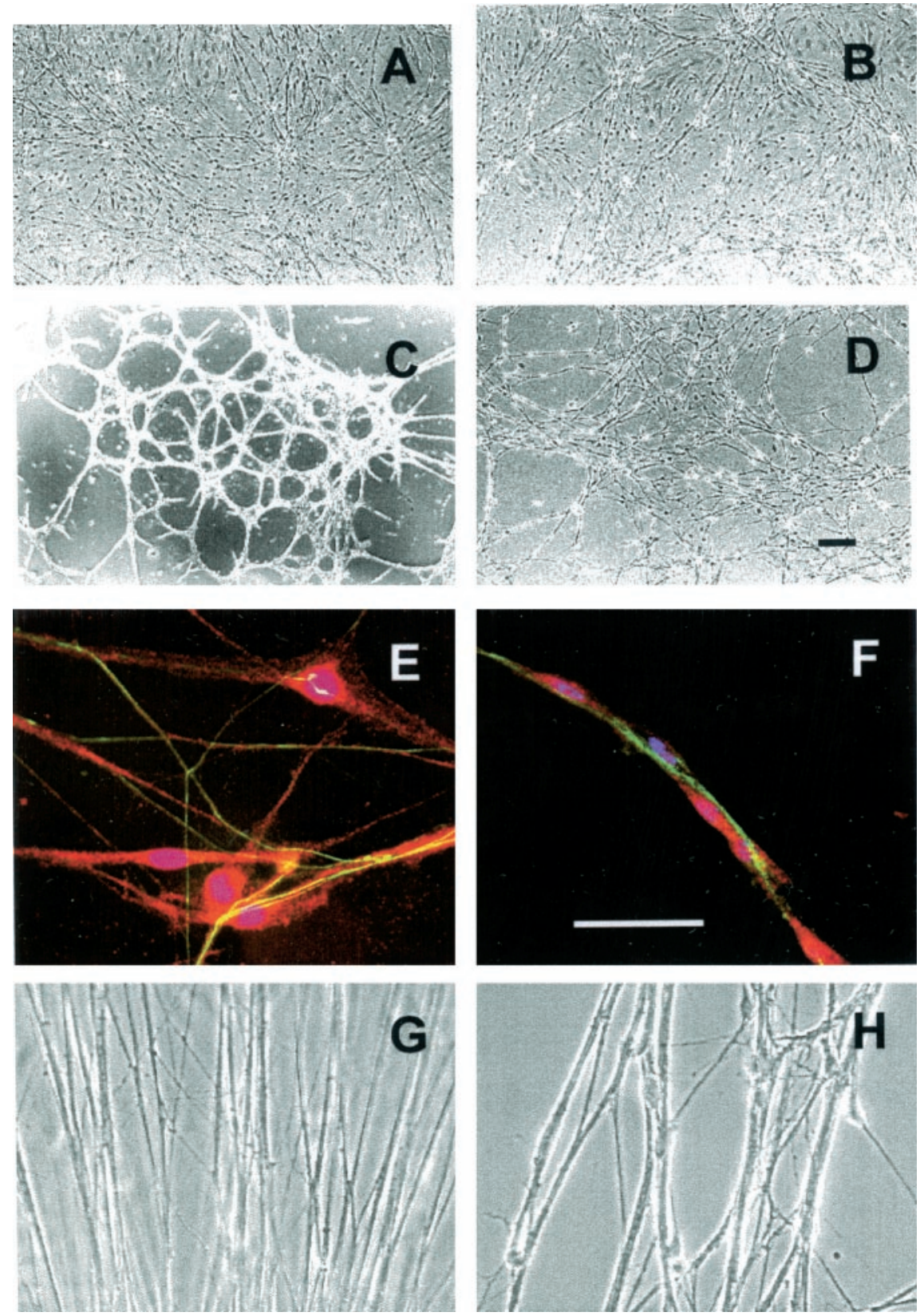

Figure 8. Organization of Schwann cell-axon units on ECM-coated surfaces. $A-F$, Dissociated rat embryo dorsal root ganglion neurons and Schwann cells were plated on dishes coated with collagen type IV $(A, E)$, collagen type $\mathrm{I}(B)$, collagen type $\mathrm{V}_{\mathrm{SC}}(C, F)$, or uncoated plastic $(D)$. The cells were cultured in serum-free medium with nerve growth factor for $4 \mathrm{~d}$. $A-D$, Low-power phase contrast images. $E, F$, Higherpower views of cultures stained with anti-neurofilament antibodies (green, stains axons), anti-S100 antibodies (red, stains Schwann cells), and 4',6diamidino-2-phenylindole (blue, stains Schwann cell nuclei). (Note that superimposition of blue and red produce magenta.) Scale bars, $100 \mu \mathrm{m}$. $G, H$, Dorsal root ganglion explants were placed on dishes coated with laminin $(G)$ or laminin plus collagen type $\mathrm{V}_{\mathrm{SC}}$ $(H)$ and cultured in serum-free medium with nerve growth factor for $4 \mathrm{~d}$. Axons were photographed using phase contrast optics near the site where they emerged from the ganglia.
1996). Other collagen-binding receptors, such as the discoidin domain receptors, could also be involved in transducing the outgrowth inhibitory signal. These transmembrane receptors contain cytoplasmic tyrosine kinase domains that are activated by collagen binding (Vogel et al., 1997). Discoidin domain receptor 1 has been shown to be involved in modulating axon extension by cerebellar granule neurons (Bhatt et al., 2000). These mechanisms are not mutually exclusive. Inhibition of outgrowth could result from the combinatorial activation of integrin- and nonintegrin-dependent receptor systems. Such a cooperative mechanism has been demonstrated in the regulation of focal adhesion assembly by fibroblasts (Saoncella et al., 1999; Couchman and Woods, 2000).

Collagen type $\mathrm{V}_{\mathrm{SC}}$ promotes migration of Schwann cells from dorsal root ganglion explants. Paradoxically, the type V collagen domain provides a poor substratum for Schwann cell adhesion. This finding is also somewhat surprising, given the expression of functional collagen-binding integrins by Schwann cells. The $\alpha 4(\mathrm{~V}) \mathrm{NTD}$, in contrast, avidly promotes Schwann cell adhesion and migration. Schwann cell adhesion to $\alpha 4(\mathrm{~V})$ does not require assembly into collagen trimers (Chernousov et al., 1996), consistent with the importance of the NTD in this process. The occurrence of a poorly adhesive protein that promotes cell migration has been described previously. For example, laminin and merosin are antiadhesive for embryonic olfactory epithelial neurons but stimulate their migration in cell culture (Calof and Lander, 1991).

Schwann cell adhesion and spreading on the NTD appear to be mediated by a heparan sulfate-dependent mechanism, suggesting that membrane heparan sulfate proteoglycans are the cellular receptors that bind this domain. The role of heparin-like glycosaminoglycans is consistent with the biochemical properties of collagen type $\mathrm{V}_{\mathrm{SC}}$. The binding affinity of $\alpha 4(\mathrm{~V})$ for heparin-like glycosaminoglycans is significantly higher than the affinity of the 
closely related $\alpha 1(\mathrm{~V})$ chain (Chernousov et al., 2000). The highaffinity heparan sulfate binding site is located in the NTD. $\alpha 4(\mathrm{~V})$-Collagen binds with high affinity to the transmembrane heparan sulfate proteoglycan syndecan-3 (Chernousov et al., 1996). $\alpha 4(\mathrm{~V})$ and syndecan-3 are synthesized by Schwann cells during the same developmental periods. Both proteins are highly expressed in peripheral nerves relative to levels in surrounding tissue (Carey et al., 1992, 1997; Chernousov et al., 1999). These findings suggest that syndecan-3 might be the Schwann cell $\alpha 4(\mathrm{~V})$ receptor.

These findings suggest a novel function for collagen type $\mathrm{V}$ during development. Early in nerve development, peripheral axons are organized into bundles that are bounded by Schwann cells and their processes (Webster et al., 1973). Later-developing axons use these bundles as tracks to direct their migration. Fasciculation of axons is produced by a combination of positive adhesive interactions among axons and repulsive signals that "hem in" the axons (Tessier-Lavigne and Goodman, 1996). As development proceeds, the axon bundles become progressively subdivided by Schwann cell processes. Electron microscopic analysis of embryonic nerves has shown that collagen fibrils are distributed around the periphery of the axon-Schwann cell bundles (Webster et al., 1973). The presence of collagen molecules that inhibit axonal migration would restrict the movement of axons away from the nerve bundles and promote fasciculation. At the same time, the NTD of collagen type $\mathrm{V}_{\mathrm{SC}}$ would promote Schwann cell spreading and migration, facilitating Schwann cell ensheathment of axons and the movement of Schwann cells along the growing nerve fiber bundles. This model is supported by the effects of collagen type $\mathrm{V}_{\mathrm{SC}}$ on the organization of sensory axons and Schwann cells in culture.

\section{REFERENCES}

Anton ES, Sandrock Jr AW, Matthew WD (1994) Merosin promotes neurite growth and Schwann cell migration in vitro and nerve regeneration in vivo. Dev Biol 164:133-146.

Bhatt RS, Tomoda T, Fang Y, Hatten ME (2000) Discoidin domain receptor 1 functions in axon extension of cerebellar granule neurons. Genes Dev 14:2216-2228.

Brittis PA, Canning DR, Silver J (1995) Chondroitin sulfate as a regulator of neuronal patterning in the retina. Science 255:733-736.

Calof AL, Lander AD (1991) Relationship between neuronal migration and cell-substratum adhesion: laminin and merosin promote olfactory neuronal migration but are anti-adhesive. J Cell Biol 115:779-794.

Campagna JA, Ruegg MA, Bixby JL (1995) Agrin is a differentiationinducing "stop signal" for motorneurons in vitro Neuron 15:1365-1374.

Carey DJ, Stahl RC (1990) Identification of a lipid-anchored heparan sulfate proteoglycan in Schwann cells. J Cell Biol 111:2053-2062.

Carey DJ, Evans DM, Stahl RC, Asundi VK, Conner KJ, Garbes P, Cizmeci-Smith G (1992) Molecular cloning and characterization of $N$-syndecan, a novel transmembrane heparan sulfate proteoglycan. J Cell Biol 117:191-201.

Carey DJ, Stahl RC, Cizmeci-Smith G, Asundi VK (1994) Syndecan-1 expressed in Schwann cells causes morphological transformation and cytoskeletal reorganization and associates with actin during cell spreading. J Cell Biol 124:161-170.

Carey DJ, Bendt KM, Stahl RC (1996) The cytoplasmic domain of syndecan-1 is required for cytoskeleton association but not detergent insolubility: identification of essential cytoplasmic domain residues. J Biol Chem 271:15253-15260.

Carey DJ, Conner K, Asundi VK, O’Mahony DJ, Stahl RC, Showalter LJ, Cizmeci-Smith G, Hartman J, Rothblum LI (1997) cDNA cloning, genomic organization and in vivo expression of rat $N$-syndecan. J Biol Chem 272:2873-2879.

Chernousov MA, Carey DJ (2000) Schwann cell extracellular matrix molecules and their receptors. Histol Histopathol 15:593-601.

Chernousov MA, Stahl RC, Carey DJ (1996) Schwann cells secrete a novel, collagen-like adhesive protein that binds $N$-syndecan. J Biol Chem 271:13844-13853.

Chernousov MA, Scherer SS, Stahl RC, Carey DJ (1999) p200, a collagen secreted by Schwann cells, is expressed in developing nerves and in adult nerves following axotomy. J Neurosci Res 56:284-294.
Chernousov MA, Rothblum K, Tyler WA, Stahl RC, Carey DJ (2000) Schwann cells synthesize type V collagen that contains a novel $\alpha 4$ chain: molecular cloning, biochemical characterization, and high affinity heparin binding of $\alpha 4(\mathrm{~V})$ collagen. J Biol Chem 275:28208-28215.

Clark EA, Brugge JS (1995) Integrins and signal transduction pathways: the road taken. Science 268:233-239.

Couchman JR, Woods A (2000) Syndecan-4 and integrins: combinatorial signaling in cell adhesion. J Cell Sci 112:3415-3420.

Delacoux F, Fichard A, Geourjon C, Garrone R, Rugggiero F (1998) Molecular features of the collagen V heparin binding site. J Biol Chem 273:15069-15076.

Dickeson SK, Mathis NL, Rahman M, Bergelson JM, Santoro SA (1999) Determinants of ligand binding specificity of the $\alpha_{1} \beta_{1}$ and $\alpha_{2} \beta_{1}$ integrins. J Biol Chem 274:32182-32191.

Dou C-L, Levine JM (1995) Inhibition of neurite growth by the NG2 chondroitin sulfate proteoglycan. J Neurosci 14:7616-7628.

Elenius K, Salmivirta M, Inki P, Mali M, Jalkanen M (1990) Binding of human syndecan to extracellular matrix proteins. J Biol Chem 265:17837-17843.

Gotz B, Scholze A, Clement A, Joester A, Schutte K, Wigger F, Frank R, Spiess E, Ekblom P, Faissner A (1996) Tenascin-C contains distinct adhesive, anti-adhesive, and neurite outgrowth promoting sites for neurons. J Cell Biol 132:681-699.

Granes F, Garcia RG, Casaroli-Marano RP, Castel S, Rocamora N, Reina M, Urena JM, Vilaro S (1999) Syndecan-2 induces filopodia by active cdc42Hs. Exp Cell Res 248:439-456.

Grinspan JB, Marchionni MA, Reeves M, Coulaloglou M, Scherer SS (1996) Axonal interactions regulate Schwann cell apoptosis in developing peripheral nerve: neuregulin receptors and the role of neuregulins. J Neurosci 16:6107-6118.

Horowitz A, Simons M (1998) Phosphorylation of the cytoplasmic tail of syndecan-4 regulates activation of protein kinase $\mathrm{C}$-alpha. J Biol Chem 273:25548-25551.

Hsiao LL, Peltonen J, Jaakkola S, Gralnick H, Uitto J (1991) Plasticity of integrin expression by nerve-derived connective tissue cells. Human Schwann cells, perineurial cells, and fibroblasts express markedly different patterns of $\beta 1$ integrins during nerve development, neoplasia and in vitro. J Clin Invest 87:811-820.

Hynes RO (1992) Integrins: versatility, modulation, and signaling in cell adhesion. Cell 69:11-25.

Hynes RO, Lander AD (1992) Contact and adhesive specificities in the associations, migrations and targeting of cells and axons. Cell 68:303-322.

Kinnunen T, Raulo E, Nolo R, Maccarana M, Lindahl U, Rauvala H (1996) Neurite outgrowth in brain neurons induced by heparin-binding growth-associated molecule (HB-GAM) depends on the specific interaction of HB-GAM with heparan sulfate at the cell surface. J Biol Chem 271:2243-2248.

Knight CG, Morton LF, Peachey AR, Tuckwell DS, Farndale RW Barnes MJ, and (2000) The collagen-binding A-domains of integrins $\alpha 1 \beta 1$ and $\alpha 2 \beta 1$ recognize the same specific amino acid sequence, GFOGER, in native (triple-helical) collagens. J Biol Chem 275:35-40.

Lein PJ, Higgins D, Turner DC, Flier LA, Terranova VP (1991) The $\mathrm{NC1}$ domain of type IV collagen promotes axonal growth in sympathetic neurons through interaction with the $\alpha 1 \beta 1$ integrin. J Cell Biol 113:417-428.

Linsenmayer TF, Gibney E, Igoe F, Gordon F, Fitch JM, Fessler LI, Birk DE (1993) Type V collagen: molecular structure and fibrillar organization of the chicken $\alpha 1(\mathrm{~V}) \mathrm{NH} 2$-terminal domain, a putative regulator of corneal fibrillogenesis. J Cell Biol 121:1181-1189.

Mahanthappa NK, Anton ES, Matthew WD (1996) Glial growth factor-2, a soluble neuregulin, directly increases Schwann cell motility and indirectly promotes neurite outgrowth. J Neurosci 16:4673-4683.

McGarvey ML, Baron-VanEvercooren A, Kleinman HK, Dubois-Dalcq M (1984) Synthesis and effects of basement membrane components in cultured rat Schwann cells. Dev Biol 105:18-28.

Milner R, Wilby M, Nishimura S, Boylen K, Edwards G, Fawcett J, Streuli C, Pytela R (1997) Division of labor of Schwann cell integrins during migration on peripheral nerve extracellular matrix ligands. Dev Biol 185:215-228.

Moradi-Ameli M, Rousseau J-C, Kleman J-P, Champliaud M-F, Boutillon M-M, Bernillon J, Wallach J, Van der Rest M (1994) Diversity in the processing events at the N-terminus of type-V collagen. Eur J Biochem 221:987-995.

Nykvist P, Tu H, Ivaska J, Kapyla J, Pihlajaniemi T, Heino J (2000) Distinct recognition of collagen subtypes by $\alpha_{1} \beta_{1}$ and $\alpha_{2} \beta_{1}$ integrins: $\alpha_{1} \beta_{1}$ mediates cell adhesion to type XIII collagen. J Biol Chem 275:8255-8261.

Oh E-S, Woods A, Couchman JR (1997) Syndecan-4 proteoglycan regulates the distribution and activity of protein kinase C. J Biol Chem 272:8133-8136.

Patton BL, Miner JH, Chiu AY, Sanes JR (1997) Distribution and function of laminins in the neuromuscular system of developing, adult and mutant mice. J Cell Biol 139:1507-1521. 
Prockop DJ, Kivirikko KI (1995) Collagens: molecular biology, diseases, and potential for therapy. Annu Rev Biochem 64:403-434.

Rahmatullah M, Schroering A, Rothblum K, Stahl RC, Urban B, Carey DJ (1998) Synergistic regulation of Schwann cell proliferation by heregulin and forskolin. Mol Cell Biol 18:6245-6252.

Rapraeger A, Jalkanen M, Bernfield M (1986) Cell surface proteoglycan associates with the cytoskeleton at the basolateral cell surface of mouse mammary epithelial cells. J Cell Biol 103:2683-2696.

Raulo E, Chernousov MA, Carey DJ, Nolo R, Rauvala H (1994) Isolation of a neuronal cell surface receptor of heparin binding growthassociated molecule (HB-GAM). J Biol Chem 269:12999-13004

San Antonio J, Karnovsky M, Gay S, Sanderson R, Lander A (1994) Interactions of syndecan-1 and heparin with human collagens. Glycobiology 4:327-332.

Sanderson R, Turnbull J, Gallagher J, Lander A (1994) Fine structure of heparan sulfate regulates syndecan-1 function and cell behavior. J Biol Chem 269:13100-13106.

Sanderson RD, Sneed TB, Young LA, Sullivan GL, Lander AD (1992) Adhesion of B lymphoid (MPC-11) cells to type I collagen is mediated by the integral membrane proteoglycan, syndecan. J Immunol 148:3902-3911.
Saoncella S, Echtermeyer F, Denhez F, Nowlen JK, Mosher DF, Robinson SD, Hynes RO, Goetinck PF (1999) Syndecan-4 signals cooperatively with integrins in a Rho-dependent manner in the assembly of focal adhesions and actin stress fibers. Proc Natl Acad Sci USA 96:2805-2810.

Saunders S, Bernfield M (1988) Cell surface proteoglycan binds mouse mammary epithelial cells to fibronectin and behaves as a receptor for interstitial matrix. J Cell Biol 106:423-430.

Syroid DE, Maycox PR, Burrola PG, Liu N, Wen D, Lee K-F, Lemke G, Kilpatrick TJ (1996) Cell death in the Schwann cell lineage and its regulation by neuregulin. Proc Natl Acad Sci USA 93:9229-9234.

Tessier-Lavigne M, Goodman CS (1996) The molecular biology of axon guidance. Science 1123-1133.

Vogel W, Gish GD, Alves F, Pawson T (1997) The discoidin domain receptor tyrosine kinases are activated by collagen. Mol Cell 1:13-23.

Webster HD, Martin JR, O'Connell MF (1973) The relationships between interphase Schwann cells and axons before myelination: a quantitative electron microscopic study. Dev Biol 32:401-416.

Zuo J, Hernandez YJ, Muir D (1998) Chondroitin sulfate proteoglycan with neurite-inhibiting activity is up-regulated following peripheral nerve injury. J Neurobiol 34:41-54. 